\title{
The Watersides of London, England *
}

London's Waterside is the theme for the London Wildlife Trust's (LWT's) supporting campaign for the Council of Europe's conservation initiative 'The Water's Edge'. It has proved an interesting theme in London, not least because it has alerted the LWT, and London's public, to the immense potential for waterside wildlife in the city. In identifying the areas in which the London Wildlife Trust could operate within the campaign, we measured no less than 290 miles $(464 \mathrm{~km})$ of the Thames and its tributaries to concentrate on, and more than 3,000 acres (1,224 ha) of reservoirs, lakes, and ponds - both natural and artificial.

The London parks thus offer us a unique opportunity, as most have a lake or pond of sorts, and London is really a trellis of buried streams and abandoned canals. The Thames itself varies greatly in nature, from its protected but wild state at Syon Park, through heavily-controlled and dredged sections in the city and docks, and even out to a tiny area of salt marsh in Bexley, at the very edge of the Greater London boundary-complete with Common Sandpipers (Tringa hypolencos) and Oystercatchers (Haematopus ostralegus).

\section{Waterside Projects}

A number of essential waterside projects have been identified by the Trust, some of which we have been able to initiate with the cooperation of London's Borough Councils as well as some commercial companies and our own members. In Camden, for example, the London Wildlife Trust submitted recommendations for the ecological development of that part of the Regents Canal stretching north from Camden Lock for two miles $(3.1 \mathrm{~km})$. This has been adopted by the Council and includes the introduction of wild species to the open water, sublittoral planting of emergent and submerged species, the preparation and planting of the canal bank itself with herbaceous species, and the management of alder and willow 'carr' along the Canal walk.

In another London Borough, Sutton, we have come to an agreement with a very different landowner, the Daughters of the Cross, who are allowing us to manage a beautiful spring-fed lake, complete with Kingcups (Marsh-marigolds, Caltha palustris). The Trust is to use one corner of the lake to test the successfulness of various methods to attract Kingfishers (Alcedo atthis). We hope to perfect a technique of building the sort of bank that Kingfishers will want to colonize, so encouraging their numbers to increase in other parts of London.

Even the once-polluted, Man-made ponds can provide a habitat for unexpected creatures-dragonflies will lay their eggs in these, from a floating log. The London Wildlife Trust is interested in improving many such ponds all over London, but particularly where open spaces are rare, in order that they can be used as educational resources for waterside ecology by local schoolchildren who do not have the opportunity to observe Nature in the raw.

* Having lived for rather many happy years on the north bank of the Thames on Chiswick Mall in Greater London before the river became so horribly polluted (but then was splendidly depolluted), we could not refrain from following the account, on pp. 83-4 of our latest issue, of the familiar features of bird-cliffs with this one of London's watersides to which the same footnote regarding their origins applies. - Ed.

\section{Old Village Ponds and Thames Foreshore}

Relics from a bygone age-the old redundant farm and village ponds in the South London Boroughs - are established habitats for wildlife, many providing a breeding spot for our internationally rare Great Crested Newt (Triturus cristatus). Encroaching housing and road development have led to their abuse, ranging from inadvertent draining to tipping. The London Wildlife Trust has earmarked ten such old ponds which, for only a relatively small expenditure of time and money but with plenty of local goodwill, could be restored to their former healthy and interesting state.

At the east end of London, the London Wildlife Trust is campaigning hard to find support for due conservation of the few remaining sections of Thames foreshore which provide a necessary feeding-ground for Shelduck (Tadorna tadorna), and for Godwit (Limosa sp. or spp.) and other waders, and we hope to strike up a good relationship with the Port of London Authority and London Dockland Development Corporation. Already the Trust has established a link with industry in the lower reaches of the Thames, and local land is increasingly a resort for the Southern Marsh Orchid (Orchis sp.), flocks of small birds such as Spotted Flycatchers (Musicapa striata) and Whitethroats (Sylvia communis), as well as more astonishing species such as the Marsh Harrier (Circus aeruginosus).

Our part in the Council of Europe's campaign was launched in October 1983 and was supported by Lord Beaumont of Witley and Stanley Johnson, then Member of the European Parliament. We also received a great deal of interest from the London Water Authorities responsible for many of the largest water-bodies in London. These have agreed to let us have information about the pollution of rivers, and about planned water-abstraction, which are apt to be the developments most threatening to the water's edge and ones which we shall be monitoring. Man-made lakes offer the London Wildlife Trust unlimited scope, ranging from the simple erection of tern landing platforms, to establishing a waterside Nature reserve complete with trails, hides, and an information centre. Just this sort of thing is needed in London, where most interested naturalists have to travel a long way to observe a good variety of birdlife at the water's edge.

\section{Diminishing Resource}

The water's edge is a fast-diminishing natural resource and one upon which very many species depend, though in some cases only for a very small part of their life-cycle. In an opposite fashion to its human population, wild species are more and more attracted to London living as the destruction of habitats in the Home Counties marches relentlessly on. $£ 100,000$ is needed forthwith for the Trust to embark on a short list of urgent projects in London, to begin to redress the balance of lost wildlife areas. As our Patron Richard Mabey said, 'The unofficial countryside is bountifully provided with water, so much have its surfaces been excavated, quarried, channelled, and generally cut up'.

Melanie Roots. Development Officer London Wildlife Trust

Thorpe Close

London W10, England, UK.

\section{Two Aspects of Life in Antarctica}

In the past it was believed that life was sparse off the coast of continental Antarctica everywhere beneath the Ross Ice-shelf-a massive sheet of ice averaging about
$366 \mathrm{~m}$ in thickness and occupying an area approximating that of France. However, recent data obtained from deepwater photography and by divers have suggested that life is 